\title{
Model for Vertical Hyperthermic Temperature Gradient Distribution in Concrete Box Girder in China
}

\author{
Ziying Liu, Tianlai Yu* \\ College of Civil Engineering, Northeast Forestry University, Harbin, China \\ Email address: \\ nefuliuziying@163.com (Ziying Liu), tianlaiyu@126.com (Tianlai Yu) \\ ${ }^{*}$ Corresponding author
}

To cite this article:

Ziying Liu, Tianlai Yu. Model for Vertical Hyperthermic Temperature Gradient Distribution in Concrete Box Girder in China. American Journal of Civil Engineering. Vol. 8, No. 3, 2020, pp. 48-56. doi: 10.11648/j.ajce.20200803.11

Received: May 1, 2020; Accepted: May 15, 2020; Published: May 18, 2020

\begin{abstract}
The temperature field of concrete box girder under sunshine is an important factor to be considered in the design of bridge superstructure. Based on the meteorological parameters and the semi-empirical formula given by related bridge specifications, the vertical temperature gradient distribution model of prestressed concrete box girder was established using SPSS software. The amplitude of the temperature gradient model is calculated according to the theory of statistics. The index function model considering wind speed, solar radiation and temperature variation was obtained, and the method to determine the amplitude of vertical temperature gradient was summarized according to different building climate zones in China. The applicable conditions of the model are as follows: sunny and cloudless days with high radiation quantity should be selected; The selected months are generally from May to July, and June in extremely cold regions. It is verified that the calculated value fits well with the measured value by monitoring data of 3 real Bridges in different zones. The model of temperature gradient heating in warm areas was calculated. For the temperate climate regions without real bridge measured data, the recommended value of temperature gradient amplitude in this region is given after trial calculation. It explores the method of using only meteorological data without surveying and mapping, which can save a lot of manpower and material resources.
\end{abstract}

Keywords: Temperature Gradient, Concrete Box Girder, Building Climate Demarcation, Meteorological Factors

\section{Introduction}

It is often found in concrete structures that due to the failure to pay enough attention to the effect of temperature, many serious cracks occur, and some Bridges are even forced to stop operation and repair, resulting in serious economic losses. Engineering studies show that the temperature stress of some parts of the bridge is greater than the load stress of the vehicle. With the development of concrete structure towards thin wall, high height, long span and prestress, the temperature effect has become a problem concerned by the engineering field at home and abroad [1-5].

Many experts and scholars analyzed and studied the temperature gradient model of concrete box girders of Bridges through observation and accumulated a lot of valuable data and successful experience. On the basis of the analysis of the actual observation data of the bridge, the United States, the United Kingdom, New Zealand, Australia and China's railway departments have proposed their own semi-empirical and semi-theoretical calculation models for the temperature distribution along the section height of the concrete box girder in the bridge design specifications (AASHTO; BS 5400; AS3600 Suppl-1994; SIA-162), and the temperature difference is used to characterize the nonlinear distribution of temperature. According to liu X. F., when the geographical latitude, azimuth, time and topographic conditions of the bridge structure are determined, the main factors affecting the sunshine temperature of the structure are solar radiation intensity, air temperature and wind speed [6]. Zhang Y. et al. proposed that the main reason for the cracks was the difference in the effect of sunlight temperature on the structure, which was transient and uneven [7]. Nie Y. D. and Robert-Wollman respectively made long-term observations on the temperature field of 3 and 1 concrete box girder Bridges in a certain region. The temperature gradient distribution patterns of concrete box girder Bridges located in their respective regions are determined [8-9]. Mase. M. A et al. made continuous observation on $250 \mathrm{~m}$ concrete box girder Bridges in Canada for more than three years, and found 
that the provisions on temperature difference in the Canadian bridge design code were unsafe [10]. Liu J. et al. calculated the temperature differences of concrete box girders in 34 major Chinese cities by building a finite element model. It is considered that the vertical temperature gradient curve is close to the form of "5th parabola at top" and "linear distribution at bottom" recommended by the New Zealand specification. The empirical formula of the temperature difference between the top and the bottom of the concrete box girder based on latitude, altitude and daily temperature difference was established [11]. Li G. Q. et al. studied the sunshine temperature field of magnetic levitation rail steel box girder, and based on the exponential function, fitted the corresponding temperature gradient curve, and compared the fitted value with the German maglev specification [12].

Nevertheless, most of these past works focus on a certain bridge instead of the building climate demarcation, or the method is too complex to design bridge actually. The bridge specifications of some countries didn't apply to China fully. The current ways to study the distribution model in the world are almost by means of actually measuring the vertical hyperthermic temperature gradient distribution of one certain bridge in the area, it leads to costly human and material resources. And the climate differences around the large China, it is not suitable for a bridge in the certain area absolutely although China has formulated the rules based on the measured data. This study explores a method that easily knows the distribution model no measurement and no waste of human and material resources but only depends on the main meteorological factors in every building climate demarcation in China.

\section{Method}

\subsection{General Description of Building Climate Demarcation in China}

Analysis for climate demarcation around of China is essential because of some reasons as follows: Climate affects the stability, durability and service standard of the bridge directly; China is vast area, complex terrain, climate great differences in every region.

It has two ways of climate division in civil engineering in China: building climate demarcation (GB50178-93) and building thermal design division (GB50176-93). In the building climate demarcation, the area of China was divided into 7 climate zones of class I and 20 ones of class II according to the three main meteorological parameters of air temperature, relative humidity and precipitation. It is based on researching the relationship between building and climate. The main indicators of the zones of class I were the mean temperature in January and July, and average relative humidity in July. The main indicators of the zones of class II were average temperature, daily range (the difference of temperature between maximum and minimum daily), maximum wind speed, etc. In the building thermal design division, it was divided into 5 climate zones according to the mean temperature in January and July all the year round, and the days of the temperature daily $\leq 5^{\circ} \mathrm{C}$ and $\geq 25^{\circ} \mathrm{C}$ all the year round: severe cold regions, cold regions, hot summer and cold winter regions, subtropical regions (hot summer and warm winter regions) and temperate climate regions. Which region or zone the representative cities of China situated in exactly based on the theory of two ways of climate division has been listed Table 1 .

Table 1. Distribution of Building Climate Demarcation for Parts of Cities in China.

\begin{tabular}{lll}
\hline Climate demarcation & Representative cities \\
\hline & $\mathrm{I}_{\mathrm{A}}$ & Mohe, Eergunayouqi \\
& $\mathrm{I}_{\mathrm{B}}$ & Jiagedaqi, Manzhouli, Heihe, etc. \\
& $\mathrm{I}_{\mathrm{C}}$ & Changchun, Haebin, Mudanjiang, Qiqihar, etc. \\
Extreme cold regions & $\mathrm{I}_{\mathrm{D}}$ & Shenyang, Huhehaote, Siping, Zhangjiakou, etc. \\
& $\mathrm{VI}_{\mathrm{A}}$ & Germu, Lenghu, Xiahe, etc. \\
& $\mathrm{VI}_{\mathrm{B}}$ & Maduo, Shenzha, etc. \\
& $\mathrm{VII}_{\mathrm{A}}$ & Kelamayi, Bole \\
& $\mathrm{VII}_{\mathrm{B}}$ & Aletai, Wulumuqi, etc. \\
& $\mathrm{VII}_{\mathrm{C}}$ & Anxi, Erlianhaote, etc. \\
& $\mathrm{II}_{\mathrm{A}}$ & Beijing, Dalian, Tianjin, Jinan, Xi'an, etc. \\
& $\mathrm{II}_{\mathrm{B}}$ & Lanzhou, Taiyuan, etc. \\
& $\mathrm{III}_{\mathrm{A}}$ & Shanghai, Zhoushan, etc. \\
& $\mathrm{VI}_{\mathrm{C}}$ & Lasa, Kanfding, etc. \\
& $\mathrm{VII}_{\mathrm{D}}$ & Tulufan, hetian, etc. \\
& $\mathrm{III}_{\mathrm{B}}$ & Chongqing, Wuhan, Jingdezhen, Hangzhou, Changsha, Guilin, etc. \\
& $\mathrm{III}_{\mathrm{C}}$ & Pingdingshan, luoyang, chengdu, etc. \\
Hot summer and cold winter regions & $\mathrm{IV}_{\mathrm{A}}$ & Hong Kong, Macao, Taipei, Haikou, etc. \\
& $\mathrm{IV}_{\mathrm{B}}$ & Guangzhou, Fuzhou, Nanning, etc. \\
Subtropical regions & $\mathrm{V}_{\mathrm{A}}$ & Guiyang, Bijie \\
& $\mathrm{V}_{\mathrm{B}}$ & Kunming, Pu'er, Xichang, Panzhihua, etc. \\
\hline
\end{tabular}

\subsection{Determination of the Temperature Gradient}

Scholars have drawn the conclusions from the analysis of data mapping: when the geographical location, bridge orientation and the time were fixed, the main factors which the temperature changes affected the concrete structure were the solar radiation strength in general, the temperature changes and the wind rate, etc. For these three major factors, the observation data in weather station were available. Therefore, this article mathematical statistics analyzed the mapping 
meteorological information in order to obtain the relation between the existing information and the concrete temperature gradient. It would save a lot of manpower and material resources in the measuring work in the future.

The comparative analysis based on the calculation results of solar temperature field under the extreme value condition in different area indicated: the index curve form adopted from railway bridges criteria was more accurate to simulate the hyperthermic temperature gradient in cross-section. And referred to the norm of New Zealand, the index curve gradient form was determined to choose finally. At the same time, many scholars recommended the index $a=5$ [13-15] for indicating the hyperthermic temperature gradient:

$$
T_{y}=T_{0} e^{-5 y}
$$

Therefore, it is only necessary to ascertain the amplitude $T_{0}$. The short-cut process of the temperature difference was analyzed by means of the method of probability statistics based on the values of temperature filed from history meteorological information. Only the sun radiating strength, speed and temperatures daily range, the solar temperature difference in bridge concrete structure would be obtained. The meteorological data derived from various meteorological information in different places and years. Calculation and analysis were done according to the ground meteorological information and the meteorological radiation information of the weather stations all over the country that applied by national meteorological information center of China. The important data included daily minimum air temperature, maximum air temperature, average air temperature, average wind speed, solar radiation totals, etc. Year span of the data is usually in 1958 and 2008, more than 50 years, it content the needs of analysis basically. Probability of statistical analyses made use of the software SPSS. The methods of linear regression analysis in SPSS was chosen to forecast the vertical temperature difference.

\section{Result}

\subsection{Mathematical Model}

The hypothesis which there are n groups observation data, are

$$
\left(x_{i 1}, x_{i 2}, \cdots, x_{i p} ; y_{i}\right) \quad \mathrm{i}=1,2, \ldots, \mathrm{n}
$$

Assuming that these data accord with relationship below:

$$
\begin{gathered}
y_{i}=\beta_{0}+\beta_{1} x_{i 1}+\beta_{2} x_{i 2}+\cdots \beta_{p} x_{i p}+\varepsilon_{\mathrm{i}=1,2, \ldots, \mathrm{n}} \\
\left\{\begin{array}{c}
y_{1}=\beta_{0}+\beta_{1} x_{11}+\beta_{2} x_{12}+\cdots+\beta_{p} x_{1 p}+\varepsilon_{1} \\
y_{2}=\beta_{0}+\beta_{1} x_{21}+\beta_{2} x_{22}+\cdots+\beta_{p} x_{2 p}+\varepsilon_{2} \\
\vdots \\
y_{n}=\beta_{0}+\beta_{1} x_{n 1}+\beta_{2} x_{n 2}+\cdots+\beta_{p} x_{n p}+\varepsilon_{n}
\end{array}\right.
\end{gathered}
$$

In the formula, $\beta_{0}, \beta_{1}, \ldots, \beta_{\mathrm{p}}$ are $(\mathrm{p}+1)$ parameters under estimation; $\varepsilon_{1}, \varepsilon_{2}, \ldots, \varepsilon_{\mathrm{n}}$ are $\mathrm{n}$ random variables independent for each other, the mean value is zero, and the variance is $\sigma^{2}$, that is to say, they all follow the same normal distribution $\mathrm{N}(0$, $\sigma^{2}$ ). This is the mathematics model of polybasic linear regression.

To estimate the population parameter $\beta=\left(\beta_{0}, \beta_{1}, \cdots, \beta_{p}\right)^{T}$ adopts the least square method. To check the significance of regression equation adopts the $\mathrm{F}$ test. To check equation regression coefficient adopts the $\mathrm{t}$ test.

\subsection{Ascertaining the Amplitude $T_{0}$}

The extreme value of solar vertical temperature difference all the year round, the corresponding dates and meteorological parameter in Beijing were listed below[16], including general radiant quantity daily, maximum air temperature, minimum air temperature, air temperature daily range, mean wind speed,

\begin{tabular}{|c|c|c|c|c|c|c|c|c|}
\hline Months & Dates & Years & $\begin{array}{l}\text { General Radiant } \\
\text { Quantity Daily }\left(\mathrm{MJ} / \mathrm{m}^{2}\right)\end{array}$ & $\begin{array}{l}\text { Maximum of Air } \\
\text { Temper-ature }\left({ }^{\circ} \mathrm{C}\right)\end{array}$ & $\begin{array}{l}\text { Minimum of Air } \\
\text { Tempe-rature }\left({ }^{\circ} \mathrm{C}\right)\end{array}$ & $\begin{array}{l}\text { Air Temperature } \\
\text { Daily Range }\left({ }^{\circ} \mathrm{C}\right)\end{array}$ & $\begin{array}{l}\text { Mean Wind } \\
\text { Speed }(\mathrm{m} / \mathrm{s})\end{array}$ & $\begin{array}{l}\text { Extremum } \\
\text { Yearly }\left({ }^{\circ} \mathrm{C}\right)\end{array}$ \\
\hline 6 & 16 & 1958 & 32.36 & 33.9 & 14.7 & 19.2 & 1.3 & 24.8 \\
\hline 5 & 22 & 1959 & 29.30 & 31.4 & 9.5 & 21.9 & 1.5 & 23.1 \\
\hline 5 & 30 & 1960 & 30.96 & 30.9 & 12.9 & 18.0 & 0.5 & 26.4 \\
\hline 5 & 30 & 1961 & 29.52 & 34.0 & 15.7 & 18.3 & 0.5 & 25.3 \\
\hline 6 & 16 & 1962 & 29.87 & 37.1 & 18.3 & 18.8 & 0.5 & 25.5 \\
\hline 5 & 8 & 1963 & 28.59 & 26.6 & 9.6 & 17.0 & 0.5 & 25.0 \\
\hline 5 & 25 & 1965 & 29.89 & 33.0 & 10.1 & 22.9 & 1.0 & 25.0 \\
\hline 7 & 20 & 1966 & 27.26 & 33.8 & 22.1 & 11.7 & 0.5 & 22.5 \\
\hline 7 & 3 & 1967 & 29.23 & 31.9 & 18.4 & 13.5 & 0.0 & 26.0 \\
\hline 5 & 2 & 1968 & 28.11 & 29.2 & 6.5 & 22.7 & 1.0 & 24.4 \\
\hline 6 & 20 & 1969 & 20.48 & 29.4 & 14.9 & 14.5 & 1.3 & 22.5 \\
\hline 7 & 1 & 1970 & 29.82 & 34.6 & 17.4 & 17.2 & 0.5 & 25.2 \\
\hline 6 & 21 & 1971 & 30.42 & 32.0 & 16.6 & 15.4 & 1.0 & 23.6 \\
\hline 6 & 10 & 1974 & 29.18 & 32.0 & 11.3 & 20.7 & 2.0 & 21.3 \\
\hline 6 & 8 & 1975 & 31.05 & 31.3 & 13.8 & 17.5 & 1.3 & 23.6 \\
\hline 6 & 17 & 1976 & 31.91 & 26.9 & 14.6 & 12.3 & 1.5 & 22.5 \\
\hline 6 & 17 & 1977 & 29.94 & 32.7 & 18.5 & 14.2 & 1.3 & 22.1 \\
\hline
\end{tabular}
extremum of vertical temperature difference yearly (extremum yearly for simplified).

Table 2. The Extreme Value of Solar Vertical Temperature Difference All the Year Round in Beijing. 


\begin{tabular}{|c|c|c|c|c|c|c|c|c|}
\hline Months & Dates & Years & $\begin{array}{l}\text { General Radiant } \\
\text { Quantity Daily }\left(\mathrm{MJ} / \mathrm{m}^{2}\right)\end{array}$ & $\begin{array}{l}\text { Maximum of Air } \\
\text { Temper-ature }\left({ }^{\circ} \mathrm{C}\right)\end{array}$ & $\begin{array}{l}\text { Minimum of Air } \\
\text { Tempe-rature }\left({ }^{\circ} \mathrm{C}\right)\end{array}$ & $\begin{array}{l}\text { Air Temperature } \\
\text { Daily Range }\left({ }^{\circ} \mathrm{C}\right) \\
\end{array}$ & $\begin{array}{l}\text { Mean Wind } \\
\text { Speed }(\mathrm{m} / \mathrm{s})\end{array}$ & $\begin{array}{l}\text { Extremum } \\
\text { Yearly }\left({ }^{\circ} \mathrm{C}\right)\end{array}$ \\
\hline 6 & 17 & 1978 & 26.16 & 33.2 & 17.9 & 15.3 & 1.0 & 20.4 \\
\hline 5 & 17 & 1979 & 29.39 & 24.7 & 7.0 & 17.7 & 2.0 & 21.3 \\
\hline 7 & 7 & 1980 & 27.53 & 33.6 & 18.5 & 15.1 & 1.0 & 21.5 \\
\hline 5 & 22 & 1981 & 26.97 & 33.4 & 14.2 & 19.2 & 0.5 & 23.5 \\
\hline 7 & 16 & 1982 & 29.84 & 33.4 & 17.7 & 15.7 & 1.8 & 21.4 \\
\hline 6 & 13 & 1983 & 30.80 & 36.9 & 16.9 & 20.0 & 1.3 & 24.0 \\
\hline 5 & 15 & 1984 & 29.46 & 27.9 & 11.6 & 16.3 & 2.3 & 20.4 \\
\hline 6 & 21 & 1985 & 29.98 & 33.9 & 18.7 & 15.2 & 1.8 & 21.1 \\
\hline 5 & 14 & 1986 & 28.58 & 29.1 & 11.9 & 17.2 & 2.0 & 20.7 \\
\hline 7 & 11 & 1987 & 27.62 & 36.1 & 21.4 & 14.7 & 0.8 & 22.2 \\
\hline 7 & 22 & 1988 & 26.58 & 35.8 & 21.8 & 14.0 & 2.0 & 18.7 \\
\hline 6 & 1 & 1989 & 24.96 & 31.7 & 17.4 & 14.3 & 0.5 & 20.8 \\
\hline 6 & 2 & 1990 & 28.82 & 30.8 & 16.5 & 14.3 & 1.0 & 22.3 \\
\hline 5 & 2 & 1991 & 28.38 & 22.5 & 4.9 & 17.6 & 1.5 & 22.3 \\
\hline 7 & 2 & 1992 & 28.33 & 32.4 & 20.9 & 11.5 & 1.5 & 20.0 \\
\hline 7 & 13 & 1993 & 26.46 & 35.5 & 19.9 & 15.6 & 1.8 & 19.2 \\
\hline 5 & 31 & 1994 & 27.10 & 33.2 & 16.0 & 17.2 & 2.0 & 19.4 \\
\hline 5 & 30 & 1995 & 28.41 & 29.3 & 14.1 & 15.2 & 1.5 & 20.9 \\
\hline 7 & 6 & 1996 & 28.80 & 35.1 & 19.1 & 16.0 & 3.0 & 18.3 \\
\hline 6 & 11 & 1997 & 26.45 & 32.2 & 15.7 & 16.5 & 2.0 & 18.7 \\
\hline 7 & 19 & 1998 & 27.68 & 34.7 & 19.6 & 15.1 & 1.8 & 20.0 \\
\hline 5 & 20 & 1999 & 27.54 & 29.4 & 11.4 & 18.0 & 2.0 & 20.0 \\
\hline 6 & 12 & 2000 & 29.46 & 35.3 & 17.3 & 18.0 & 2.3 & 20.4 \\
\hline 5 & 9 & 2001 & 27.21 & 27.6 & 8.7 & 18.9 & 2.0 & 20.4 \\
\hline 7 & 7 & 2002 & 27.72 & 35.1 & 20.6 & 14.5 & 1.3 & 20.8 \\
\hline 7 & 8 & 2003 & 27.83 & 31.1 & 18.3 & 12.8 & 2.0 & 18.9 \\
\hline
\end{tabular}

The information was statistics analyzed by virtue of software SPSS. Finally a series of data were obtained as follows:

Table 3. Mean Value and Standard Deviations of the Four Projects.

\begin{tabular}{llll}
\hline Project Name & Sample Size & Mean Value & Standard Deviation \\
\hline General Radiant Quantity Daily & 46 & 28.64 & 2.027 \\
Air Temperature Daily Range & 46 & 16.63 & 2.667 \\
Mean Wind Speed & 46 & 1.37 & 0.66 \\
Extremum Yearly & 46 & 22.09 & 2.167 \\
\hline
\end{tabular}

Table 4. K-S Testing of Single Sample.

\begin{tabular}{llllllll}
\hline \multirow{2}{*}{$\mathbf{N}$} & \multicolumn{2}{l}{ Orthostate Parameter } & \multicolumn{2}{c}{ Extreme Difference } & \multirow{2}{*}{ K-S Testing Value } & $\begin{array}{l}\text { Approached Significance p } \\
\text { (Bilateral) }\end{array}$ \\
\cline { 2 - 6 } & $\begin{array}{l}\text { Mean } \\
\text { Value }\end{array}$ & $\begin{array}{l}\text { Standard } \\
\text { Deviation }\end{array}$ & Absolute Value & Plus & Minus & & \\
\hline 46 & 22.089 & 2.167 & 0.085 & 0.085 & -0.069 & 0.579 & 0.891 \\
\hline
\end{tabular}

The analysis results from table 3 and table 4 show: $\mathrm{p}=0.891>0.05$, extremum of vertical temperature difference yearly accords with normal distribution. Mathematical model which the general radiant quantity daily, the air temperature daily range, the mean wind speed served as independent variable, the extremum yearly served as dependent variable was established with the method of multiple linear regression.

Table 5. Correlation Analysis.

\begin{tabular}{lllll}
\hline & & Air Temperature Daily Range & Mean Wind Speed & Extremum Yearly \\
\hline \multirow{2}{*}{ General Radiant } & Pearson Correlation & 0.280 & 0.000 & $0.431^{* *}$ \\
Quantity Daily & Significance(Bilateral) & 0.060 & 0.998 & 0.003 \\
& N & 46 & 46 & 46 \\
Air Temperature & Pearson Correlation & 1 & 0.049 & $0.374^{*}$ \\
Daily Range & Significance(Bilateral) & -- & 0.748 & 0.010 \\
& N & -- & 46 & 46 \\
Mean Wind Speed & Pearson Correlation & -- & 1 & $-0.768^{* *}$ \\
& Significance(Bilateral) & -- & -- & 0.000 \\
& N & -- & -- & 46 \\
\hline
\end{tabular}

**, significant correlation in the level of 0.01 (Bilateral)

*, significant correlation in the level of 0.05 (Bilateral) 
The analysis results from table 5 indicated that the correlation among the general radiant quantity daily, the air temperature daily range, the mean wind speed and the extremum yearly possessed statistical significance. From the correlation coefficient R, It was thus clear that the relativity the mean wind speed to extremum yearly was the largest, and it was negative correlation; the general radiant quantity daily took second place, the air temperature daily range was the least.

The gradual return method was adopted in multiple regression. To check the significance of regression equation adopts the $\mathrm{F}$ test. The analysis results from table 6 showed that Adjusted R-Squared $\mathrm{R}_{\text {adj }}^{2}=0.858$, it was close to 1 ; Variance $\mathrm{F}=91.684$, and the significance $\mathrm{p}$ was close to 0 , indicating the effect of regession was better, The whole equation possessed statistical significance.

Table 6. Variance Analysis ${ }^{d}$.

\begin{tabular}{|c|c|c|c|c|c|c|}
\hline Model & $\begin{array}{l}\text { Multiple Correlation } \\
\text { Coefficient } \mathbf{R}\end{array}$ & $\begin{array}{l}\text { Coefficient of } \\
\text { Determination } R^{2}\end{array}$ & $\begin{array}{l}\text { Adjusted R-Squared } \\
\mathbf{R}_{\text {adj }}^{2}\end{array}$ & $\begin{array}{l}\text { Standard Error of } \\
\text { Estimate }\end{array}$ & Variance F & Significance Sig. \\
\hline 3 & $0.931^{\mathrm{c}}$ & 0.868 & 0.858 & 0.8164 & 91.684 & $0.000^{\mathrm{c}}$ \\
\hline
\end{tabular}

c. predictive variable: (constant), mean wind speed, general radiant quantity daily, air temperature daily range.

d. dependent variable: extremum of vertical temperature difference yearly

To check equation regression coefficient adopted the $t$ test [see Table 7]. In colinearity statistics, the value of the variance inflation factor were lower, thus there wasn't a serious problem of multiple colinearity. Therefore, the three independent variables could be inducted into the equation.

Table 7. Partial Correlation Coefficient Analysis ${ }^{a}$.

\begin{tabular}{|c|c|c|c|c|c|c|c|c|}
\hline \multirow{2}{*}{\multicolumn{2}{|c|}{ Model }} & \multicolumn{2}{|c|}{$\begin{array}{l}\text { Nonstandardized } \\
\text { Technique Coefficient }\end{array}$} & \multirow{2}{*}{$\begin{array}{l}\begin{array}{l}\text { Standard } \\
\text { Coefficient }\end{array} \\
\text { Bata }\end{array}$} & \multirow{2}{*}{$\mathbf{t}$} & \multirow{2}{*}{ Sig. } & \multicolumn{2}{|c|}{ Colinearity Statistical Quantity } \\
\hline & & B & $\begin{array}{l}\text { Standard } \\
\text { Error }\end{array}$ & & & & Tolerance & $\begin{array}{l}\text { Variance Inflation } \\
\text { Factor VIF }\end{array}$ \\
\hline \multirow{2}{*}{1} & (constant) & 25.551 & 0.482 & -- & 52.999 & 0.000 & -- & -- \\
\hline & Mean Wind Speed & -2.519 & 0.317 & -0.768 & -7.950 & 0.000 & 1.000 & 1.000 \\
\hline \multirow{2}{*}{2} & (constant) & 12.341 & 2.241 & & 5.507 & 0.000 & & \\
\hline & General Radiant Quantity Daily & 0.461 & 0.077 & 0.431 & 5.973 & 0.000 & 1.000 & 1.000 \\
\hline \multirow{4}{*}{3} & (constant) & 10.847 & 1.764 & -- & 6.148 & 0.000 & -- & -- \\
\hline & Mean Wind Speed & -2.570 & 0.185 & -0.783 & -13.931 & 0.000 & 0.997 & 1.003 \\
\hline & General Radiant Quantity Daily & 0.367 & 0.063 & 0.343 & 5.864 & 0.000 & 0.922 & 1.085 \\
\hline & Air Temperature Daily Range & 0.257 & 0.048 & 0.316 & 5.396 & 0.000 & 0.919 & 1.088 \\
\hline
\end{tabular}

a. dependent variable: extremum of vertical temperature difference yearly

The final model is:

$$
T_{0}=y=10.847-2.570 x_{1}+0.367 x_{2}+0.257 x_{3}
$$

\subsection{Parameter Value Considerations}

If the least favorable values of various meteolorigic factors were combinated simply as the controlling condition to calculate the solar temperature distribution of concrete box girder, it is not appropriate for the complexity of meteorologic parameter system. The results if doing it like that would over-estimate the gradient temperature difference. therefore, the rules that we selected the values of the three arguments should try to operate as follows:

1. Select the fine and cloudless, and ample radiation days.

2. To select one day in May to July as the radiant quantity is the most powerful; it can be in April to broaden. Because there were distinctions in the different building climate demarcations, the months selected to calculate were difference. For example, June was select in extreme cold regions, whereas July was select in hot summer and cold winter regions. Also, the average value in some days can be adopted to reduce errors.

To take Mudanjiang, Heilongjiang province for example, it stays in the extreme cold area. Line chart was drawn in Figure 1 to Figure 3 according to mean radiation daily, mean air temperature, mean wind speed in one month in 1999-2008 separately.

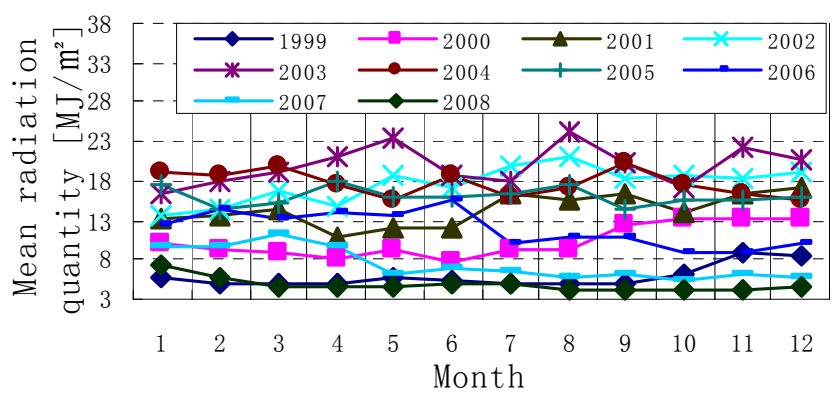

Figure 1. Mean daily radiation quantity of every month in Harbin area in 1999-2008 (Harbin instead of Mudanjiang for no the corresponding information, and the values of these two cities almost have no distinction). 


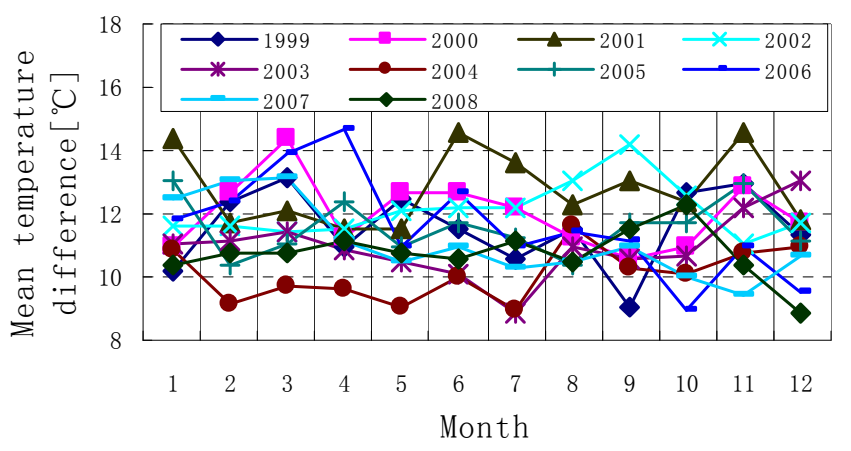

Figure 2. Mean air temperature difference of every month in Mudanjiang area in 1999-2008.

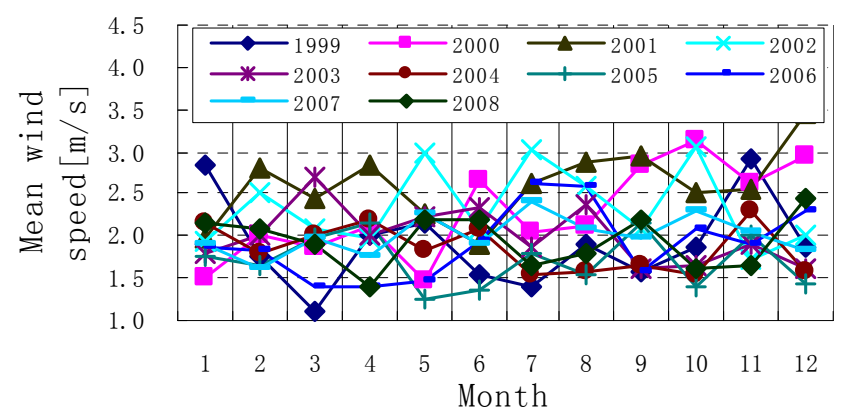

Figure 3. Mean wind speed of every month in Mudanjiang area in 1999-2008.

The conclusions reached from the figures are: The mean daily radiation quantity was the largest in May to July every year, and the maximum of the daily radiation quantity usually appeared in June in most years [see Figure 1]. Every May to July in 1999-2008, mean temperature difference presented the trends toward decreasing by degrees month by month in most of the years. Nevertheless, the amplitude of variation is not large. Therefore May to July could be selected to calculate the amplitude of vertical hyperthermic temperature gradient [see Figure 2]. In most of the years, the maximum value of mean wind speed appeared in March to May, the next was June. Considering the formula (3), the absolute value of the impact factor of mean wind speed was larger than the other independent variable, the inference that the mean wind speed occupied a larger proportion could be formed in the course of ascertaining the vertical temperature difference. Therefore, April that mean wind speed was the largest could be brought into the range of the reference month.

Horizontal trends that every May to July in decade were taken into account when ascertained the months in detail. Moreover, with global climate warming, the parameters such as daily radiation, air temperature difference daily and mean wind speed, etc. may well some changes. So the changing trends of the three factors in every May to July in decade were analyzed [Figure 4 to Figure 6].

According to the figures, the rangeability of the general radiant quantity daily was not large, whereas the mean temperature difference of May to July appeared a obvious turning point in 2003, it kept a smooth state from 2004 up to now, and the trend of the temperature difference turned smaller more and more generally [see Figure 4]. mean wind speed arose obvious variation for one time in 2004, since then, the variation is not large like that. Therefore, to take the various parameter values of five years nearby for reference is significant when to calculate. And the maximum value among the years also can be taken sometimes for the safer and more conservative computing results when transforming an old bridge. The value can be adopted by inquiring about the Figures 4 to 6 .

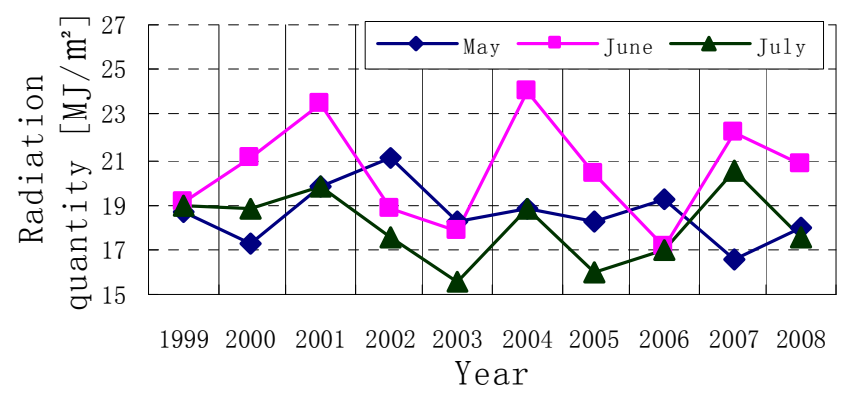

Figure 4. Mean daily radiation quantity of every month of May to July in 1999-2008 in Harbin.

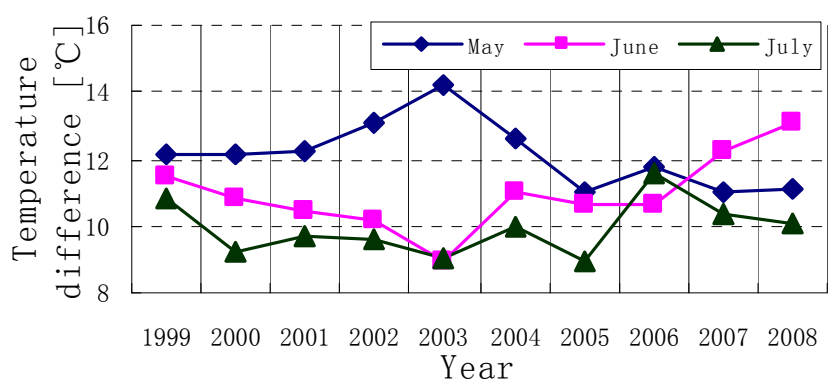

Figure 5. Mean temperature difference of every month of May to July in 1999-2008 in Mudanjiang.

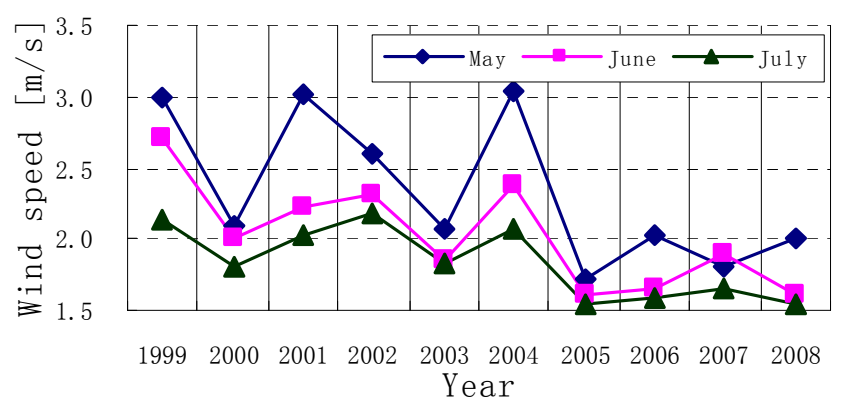

Figure 6. Mean wind speed of every month of May to July in 1999-2008 in Mudanjiang.

That is worthy to say, the general radiant quantity daily in Mudanjiang region could be found for contrasting and analyzing, so the corresponding values were instead for their close quarters.

Similarly, to analyze the meteorological data in hot summer and cold winter regions took Nanjing city, Jiangsu province for example. The values of general radiant quantity daily also were instead by Wuhan city nearly. 


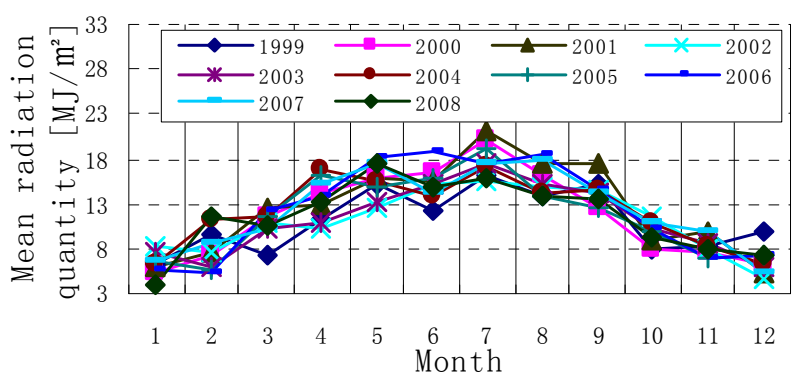

Figure 7. Mean daily radiation quantity of every month in Wuhan area in 1999-2008

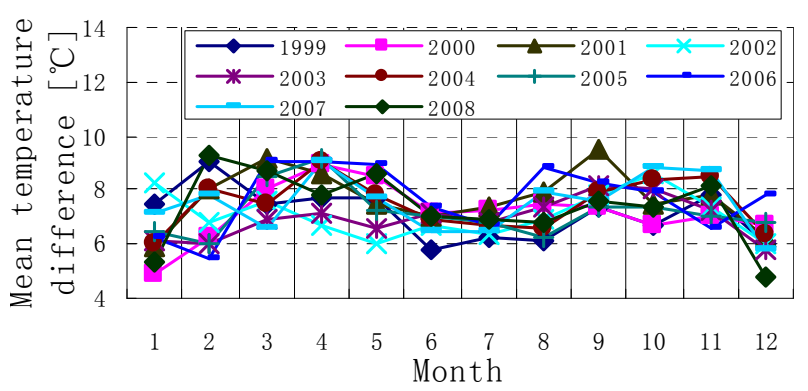

Figure 8. Mean air temperature difference of every month in Nanjing area in 1999-2008.

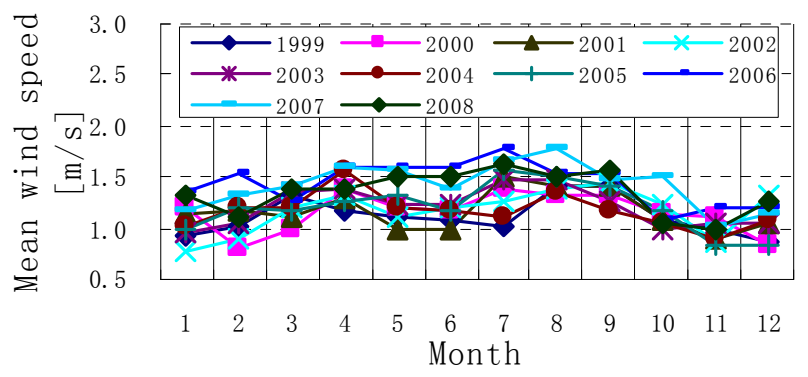

Figure 9. Mean wind speed of every month in Nanjing area in 1999-2008.
According to the figures, the peak value of radiation quantity arose in July to August. The value of temperature difference was larger in May, and it remained stable state in June to August. The mean wind speed was larger in July than the other months in the year. So July is the best to calculate and analyze.

3. After ascertaining the computing month, the method how to select the date in that month was to look for the conditions: lower wind speed and larger air temperature difference in one day. In every building climate demarcations, the independent values selected were slightly different, to analyze the behaviour of meteorological information and to select the values then according to the data rendered by national meteorological center could really reflect the situations of local temperature gradient.

4. The cities in certain regions, such as plateau or alongshore, etc., should be considered the inflections of special factors although they stays in the same building climate demarcation with other ones. The way is add factors properly. How to ascertain the coefficients of the added parameters can rebuild a formula according to the method aforementioned.

\section{Validation and Prediction}

\subsection{Compare Statistic to Measured Value}

A representative bridge was selected from each building climate demarcation nationwide (except temperate climate regions for no data) in order to check the correction of the model above-mentioned [see Table 8], but no considering the temperature difference of beam bottom.

Table 8. Cross-references of the Model for Vertical Hyperthermic Temperature Gradient Distribution of Prestressed Concrete rigid Framework- continuous Box Girder in Every Building Climate Demarcation.

\begin{tabular}{|c|c|c|c|c|c|c|c|c|c|}
\hline \multirow{2}{*}{$\begin{array}{l}\text { Name of } \\
\text { Bridges }\end{array}$} & \multirow[t]{2}{*}{ Location } & \multirow{2}{*}{$\begin{array}{l}\text { Building } \\
\text { Climate } \\
\text { Regions } \\
\end{array}$} & \multirow{2}{*}{ Latitude $\left(^{\circ}\right)$} & \multirow{2}{*}{$\begin{array}{l}\text { Longitu } \\
\text { de }\left(^{\circ}\right)\end{array}$} & \multirow{2}{*}{$\begin{array}{l}\text { Total } \\
\text { Length of } \\
\text { Bridge }(\mathrm{m})\end{array}$} & \multirow[t]{2}{*}{ Structural Style } & \multicolumn{2}{|c|}{$\begin{array}{l}\text { Formula of Temperature } \\
\text { Gradient } T y=T_{0} e^{-a y}\end{array}$} & \multirow{2}{*}{$\begin{array}{l}\text { Date of } \\
\text {-Experiment }\end{array}$} \\
\hline & & & & & & & $\overline{T_{0}}$ & $\mathbf{a}$ & \\
\hline $\begin{array}{l}\text { Sanguxian } \\
\text { viaduct }\end{array}$ & $\begin{array}{l}\text { Hailin-Yabuli in } \\
\text { Heilongjiang } \\
\text { province }\end{array}$ & $\begin{array}{l}\text { Extreme cold } \\
\text { regions }\end{array}$ & N44.8 & -- & 287.5 & $\begin{array}{l}\text { prestressed concrete } \\
\text { rigid framework- } \\
\text { continuous box girder } \\
\text { system }\end{array}$ & 22 & 5 & $\begin{array}{l}\text { Sept. 12-13, } \\
2007\end{array}$ \\
\hline $\begin{array}{l}\text { Huluhe grand } \\
\text { bridge in } \\
\text { Expwy } \\
\text { Huangyan }\end{array}$ & $\begin{array}{l}\text { Huangling } \\
\text { county, Yan'an } \\
\text { city in Shanxi } \\
\text { province }\end{array}$ & Cold regions & N35.55 & E109.32 & 1460 & $\begin{array}{l}\text { prestressed concrete } \\
\text { rigid framework- } \\
\text { continuous box girder } \\
\text { system }\end{array}$ & 21.3 & 5.2 & Oct. 21,2005 \\
\hline $\begin{array}{l}\text { Beicha bridge } \\
\text { on the long } \\
\text { river }\end{array}$ & $\begin{array}{l}\text { Nanjing city in } \\
\text { Jiangsu } \\
\text { province }\end{array}$ & $\begin{array}{l}\text { Hot summer and } \\
\text { cold winter } \\
\text { regions }\end{array}$ & $\mathrm{N} 34.26$ & E117.18 & 2212 & $\begin{array}{l}\text { prestressed concrete } \\
\text { continuous box girder } \\
\text { bridge }\end{array}$ & 20 & 5 & May 4, 2000 \\
\hline $\begin{array}{l}\text { Aids to } \\
\text { navigation } \\
\text { bridge in } \\
\text { Humen }\end{array}$ & $\begin{array}{l}\text { Humen town, } \\
\text { Dongguan city } \\
\text { in Guangdong } \\
\text { province }\end{array}$ & $\begin{array}{l}\text { Subtropical } \\
\text { regions }\end{array}$ & $\mathrm{N} 22.82$ & E113.67 & -- & $\begin{array}{l}\text { prestressed concrete } \\
\text { rigid framework- } \\
\text { continuous box girder } \\
\text { system }\end{array}$ & 23 & 5.3 & $\begin{array}{l}\text { Nov. 12-15, } \\
2003\end{array}$ \\
\hline
\end{tabular}

By looking through the wind speed, general radiant quantity daily, maximum and minimum of air temperature daily, etc. of the cities that the four bridges located in below, the dates selected were the day of the maximum general radiant quantity daily in every month. The calculation didn't give consideration to the smaller wind speed and the larger air temperature daily for strength reduction. However, the correction of the conclusion was still verified and proved 
under this condition. The meteorological values were substituted into the formula (3), and compared the values of the vertical temperature gradient that the bridges were selected in three building climate demarcations of Table 8 . In every regions the information was listed according to the sequence of the values of the vertical temperature difference in Tables 9 to 11 .

Table 9. Calculated Values of Vertical Temperature Difference of Sanguxian Viaduct.

\begin{tabular}{|c|c|c|c|c|c|c|c|c|}
\hline Month & Date & Year & $\begin{array}{l}\text { General Radiant } \\
\text { Quantity Daily } \\
\left(\mathbf{M J} / \mathbf{m}^{2}\right)\end{array}$ & $\begin{array}{l}\text { Maximum of Air } \\
\text { Temperature } \\
\text { Daily }\left({ }^{\circ} \mathrm{C}\right) \\
\end{array}$ & $\begin{array}{l}\text { Minimum of Air } \\
\text { Temperature } \\
\text { Daily }\left({ }^{\circ} \mathrm{C}\right)\end{array}$ & $\begin{array}{l}\text { Temperature } \\
\text { Difference } \\
\left({ }^{\circ} \mathrm{C}\right) \\
\end{array}$ & $\begin{array}{l}\text { Mean Wind } \\
\text { Speed }(\mathrm{m} / \mathrm{s})\end{array}$ & $\begin{array}{l}\text { Vertical } \\
\text { Temperature } \\
\text { Difference }\left({ }^{\circ} \mathrm{C}\right)\end{array}$ \\
\hline 6 & 14 & 2008 & 30.02 & 26.9 & 10.6 & 16.3 & 11 & 23.22644 \\
\hline 8 & 5 & 2004 & 26.41 & 28.8 & 14.2 & 14.6 & 8 & 22.23567 \\
\hline 9 & 3 & 2000 & 22.65 & 29.7 & 15.3 & 14.4 & 3 & 22.08935 \\
\hline 5 & 21 & 2005 & 28.02 & 22.9 & 8.3 & 14.6 & 11 & 22.05554 \\
\hline 5 & 27 & 2002 & 27.81 & 26.4 & 8 & 18.4 & 15 & 21.92707 \\
\hline
\end{tabular}

Table 10. Calculated Values of Vertical Temperature Difference of Beicha Bridge on the Long River.

\begin{tabular}{|c|c|c|c|c|c|c|c|c|}
\hline Month & Date & Year & $\begin{array}{l}\text { General Radiant } \\
\text { Quantity Daily } \\
\left(\mathbf{M J} / \mathbf{m}^{2}\right)\end{array}$ & $\begin{array}{l}\text { Maximum of Air } \\
\text { Temperature Daily } \\
\left({ }^{\circ} \mathrm{C}\right)\end{array}$ & $\begin{array}{l}\text { Minimum of Air } \\
\text { Temperature } \\
\text { Daily }\left({ }^{\circ} \mathrm{C}\right)\end{array}$ & $\begin{array}{l}\text { Temperature } \\
\text { Difference } \\
\left({ }^{\circ} \mathrm{C}\right)\end{array}$ & $\begin{array}{l}\text { Mean Wind } \\
\text { Speed }(\mathrm{m} / \mathrm{s})\end{array}$ & $\begin{array}{l}\text { Vertical } \\
\text { Temperature } \\
\text { Difference }\left({ }^{\circ} \mathrm{C}\right)\end{array}$ \\
\hline 4 & 30 & 2003 & 25.32 & 24 & 10.8 & 13.2 & 5 & 22.19534 \\
\hline 5 & 23 & 2002 & 26.83 & 25.5 & 15.2 & 10.3 & 5 & 22.00421 \\
\hline 5 & 21 & 2000 & 25.84 & 34.8 & 18 & 16.8 & 10 & 21.98188 \\
\hline 4 & 16 & 2000 & 25.17 & 20.7 & 7.5 & 13.2 & 10 & 20.81079 \\
\hline 7 & 9 & 2002 & 26.79 & 31.1 & 21.8 & 9.3 & 8 & 20.93483 \\
\hline
\end{tabular}

Table 11. Calculated Values of Vertical Temperature Difference of Aids to Navigation Bridge.

\begin{tabular}{|c|c|c|c|c|c|c|c|c|}
\hline Month & Date & Year & $\begin{array}{l}\text { General Radiant } \\
\text { Quantity Daily } \\
\left(\mathbf{M J} / \mathbf{m}^{2}\right) \\
\end{array}$ & $\begin{array}{l}\text { Maximum of Air } \\
\text { Temperature Daily } \\
\left({ }^{\circ} \mathrm{C}\right)\end{array}$ & $\begin{array}{l}\text { Minimum of Air } \\
\text { Temperature } \\
\text { Daily }\left({ }^{\circ} \mathrm{C}\right) \\
\end{array}$ & $\begin{array}{l}\text { Temperature } \\
\text { Difference } \\
\left({ }^{\circ} \mathrm{C}\right) \\
\end{array}$ & $\begin{array}{l}\text { Mean Wind } \\
\text { Speed }(\mathrm{m} / \mathrm{s})\end{array}$ & $\begin{array}{l}\text { Vertical } \\
\text { Temperature } \\
\text { Difference }\left({ }^{\circ} \mathrm{C}\right) \\
\end{array}$ \\
\hline 4 & 12 & 2002 & 23.22 & 25.7 & 11.4 & 5 & 14.3 & 21.70734 \\
\hline 5 & 7 & 2007 & 25.38 & 34 & 19.8 & 9 & 14.2 & 21.41076 \\
\hline 5 & 10 & 1999 & 22.49 & 29.4 & 16.2 & 5 & 13.2 & 21.15673 \\
\hline 6 & 5 & 2009 & 25.47 & 34.2 & 22.5 & 9 & 11.7 & 20.80129 \\
\hline 8 & 1 & 2002 & 23.3 & 34.6 & 23.7 & 5 & 10.9 & 20.8629 \\
\hline
\end{tabular}

The corresponding values were instead for their close cities because the general radiant quantity daily in parts of regions could be queried in calculating process. Year span is usually in 1999-2009, whereas in 1999-2003 in Lanzhou (Huangyan) region only.

The conclusion can be found that the values computed by means of statistics and analysis were closely to the measured ones from the computing results above.

\subsection{Speculation for Temperate Climate Regions}

The values of temperate climate regions would be speculated Because of no the measured results of representative bridges to refer at present. That can give designers prop for computing and analyzing. The amplitude of vertical temperature gradient in warm regions (take Kunming city for example) was speculated by the methods aforementioned [see Table 12].

Table 12. Predicted Values of Vertical Temperature Difference in Temperate Climate Regions.

\begin{tabular}{|c|c|c|c|c|c|c|c|c|}
\hline Month & Date & Year & $\begin{array}{l}\text { General Radiant } \\
\text { Quantity Daily } \\
\left(\mathbf{M J} / \mathbf{m}^{2}\right)\end{array}$ & $\begin{array}{l}\text { Maximum of Air } \\
\text { Temperature Daily } \\
\left({ }^{\circ} \mathrm{C}\right)\end{array}$ & $\begin{array}{l}\text { Minimum of Air } \\
\text { Temperature } \\
\text { Daily }\left({ }^{\circ} \mathrm{C}\right)\end{array}$ & $\begin{array}{l}\text { Temperature } \\
\text { Difference } \\
\left({ }^{\circ} \mathrm{C}\right)\end{array}$ & $\begin{array}{l}\text { Mean Wind } \\
\text { Speed }(\mathrm{m} / \mathrm{s})\end{array}$ & $\begin{array}{l}\text { Vertical } \\
\text { Temperature } \\
\text { Difference }\left({ }^{\circ} \mathrm{C}\right)\end{array}$ \\
\hline 5 & 13 & 2000 & 27.08 & 24.4 & 12.5 & 10 & 11.9 & 21.27366 \\
\hline 6 & 6 & 1999 & 26.74 & 29.1 & 13.0 & 15 & 16.1 & 20.94328 \\
\hline 5 & 5 & 2007 & 29.33 & 26.9 & 10.5 & 19 & 16.4 & 20.94291 \\
\hline 8 & 11 & 2004 & 30.58 & 28.4 & 16.9 & 16 & 11.5 & 20.91336 \\
\hline 5 & 9 & 1999 & 25.99 & 22.5 & 7.0 & 15 & 15.5 & 20.51383 \\
\hline
\end{tabular}

The value of vertical temperature gradient predicted from the Table 12 was

$$
T_{y}=20.9 e^{-5 y}
$$

\section{Conclusions}

The main solar temperature changes in bridge structure are the solar radiation strength, temperature changes and wind speed, etc. in this study, index curved model considered the three factors was found with the method of linear regression by software SPSS based on a great many meteorological information supplied by China meteorological data sharing service system, and the index readystate was $\mathrm{a}=5$ by the contrast to the bridge specification of some counties, only the amplitudes $\mathrm{T}_{0}$ were difference in the formula deduced: 
$\mathrm{T}_{0}=10.847-2.570 \mathrm{x}_{1}+0.367 \mathrm{x}_{2}+0.257 \mathrm{x}_{3}$. How to select the eingabewert has been summarized based on the various buildings climate demarcations in China. Such days would be selected as fine and cloudless, ample radiation, low wind speed, and large air temperature change as far as possible; the months selected usually were in May to July, April sometimes, and June was select in extreme cold regions, whereas July was select in hot summer and cold winter regions, etc. A representative bridge was selected from each building climate demarcation nationwide in order to check the correction of the model, and the better fitting was concluded at last. Finally the values of temperate climate regions were speculated with the formula deduced.

The idea of building climate demarcation was innovatively brought into research as computing the model for vertical temperature gradient. Moreover, the viewpoint that the temperature gradient can be obtained without measurement but the main meteorological data only.

\section{Acknowledgements}

This work was funded by Basic Scientific Research Operating Expenses of Central Universities (No. 2572015BB03), Longjian Road and Bridge Co., LTD. Science and Technology Project (No. LJKY004-2017) and National Natural Science Foundation of China (NSFC) (No. 51408258). These supports are gratefully acknowledged. Also acknowledged is the national meteorological information center for applied various historical materials and data about radiant and geoclimatic meteorology.

\section{Notation}

The following symbols are used in this paper:

$\mathrm{T}_{0}=$ temperature difference in altitude of box girder; and

$\mathrm{T}_{\mathrm{y}}=$ temperature difference of calculated point;

$\mathrm{x}_{1}=$ mean wind speed; and

$\mathrm{x}_{2}=$ general radiant quantity daily; and

$\mathrm{x}_{3}=$ air temperature daily range

$\mathrm{x}_{\mathrm{i} 1}, \mathrm{x}_{\mathrm{i} 2}, \ldots, \mathrm{x}_{\mathrm{ip}}=$ independent variable

$\mathrm{y}_{\mathrm{i}}=$ dependent variable

$\beta_{0}, \beta_{1}, \ldots, \beta_{\mathrm{p}}=$ overall return parameter;

$\varepsilon_{\mathrm{i}}=$ residual

\section{References}

[1] B. Hunt and N. Cooke (1975). "Thermal Calculations for Bridge Design,” Journal of the Structural Division, 176-178.

[2] Wang J. F., Zhang J. T., Yang A. X. and Xu R. Q. (2020). "Control Measures for Thermal Effects During Placement of Span-Scale Girder Segments on Continuous Steel Box Girder Bridges," Journal of Zhejiang University-SCIENCE A (Applied Physics \& Engineering), 21 (4), 255-267.
[3] Zhao R. D., Wang Y. B. (2016). "Studies on Temperature Field Boundary Conditions for Concrete Box-Girder Bridges Under Solar Radiation," China Journal of Highway and Transport, 29 (7), 52-61.

[4] Zhang L. L., Wu L. Q., Yang L. (2012) "Analysis of Temperature Field Of Concrete Box Girder And Secondary Development Of Program," Journal of Convergence Information Technology, 7 (5), 254-262.

[5] Jiang C. R., Ren, J. M. and Wang, Z. L. (2013). "Research of Temperature Field of Long Span Concrete Box Girder Bridge Caused by Solar Radiation," Applied Mechanics and Materials, 256-259 (PART 1), 1635-1639

[6] Liu X. F. (1985). "Temperature distribution of concrete bridge," Journal Railway Engineering Society, 107-111.

[7] Zhang, Y., Hu, Z. T., Jia, R. Z. (2006). "Temperature Gradient of Reinforced Concrete Continuous Curved Box Girder Bridge," Journal Chang'an University, 26 (7), 58-62.

[8] Nie Y. D. (2013). "Analysis of temperature field and temperature effect for long span concrete box girder bridges in cold regions," Doctoral Dissertation of Harbin Institute of Technology, 66-70.

[9] L. Roberis-Wollman, C. Cawrse, E Breen J. (2002). "Measurement of Thermal Gradients and Their Effects on Segmental Concrete Bridge," Journal of Structural Engineering, 3 (7), 166-174.

[10] N. Li D., A. Maes M. and H. Dilger (2008). "Evaluation of Temperature Data of Confederation Bridge: Thermal Loadingand Movement at Expansion Joint," Proceeding of The ASCE: Structure Congress, 1 (120), 314-324.

[11] Liu J., Liu Y. J., Bai, Y. X. and Liu G. L. (2020). "Regional Variation and Zoning of Temperature Gradient Pattern of Concrete Box Girder," China Journal of Highway Transportation. 33 (3), 73-84.

[12] Li G. Q., Wang C. A., Ye F. and Chen S. W. (2019). "Research on Temperature Field and Thermal Deformation of Steel Box Maglev Guideway Caused by Solar Radiation," China Civil Engineering Journal. 52 (11), 45-55.

[13] Sheng C. and Yu T. L. (2008). "Research and Temperature Effects on Continuous Rigid Frame Box Beam Bridge," Forest Engineering. 24 (5), 49-96.

[14] Cui X. Q., Feng. R. and Huang Y. (2010) "Study on Temperature Field of Concrete Box Girder Bridge by Solar Radiation," Concrete, 6, 37-40.

[15] Li H. J., Li, Z. and Wang Y. J., etc.(2005) "Research on Temperature Gradient of Concrete Box Girder of Continuous Rigid-Frame Bridge Named Aids to Navigation Bridge in Town Humen, Guangdong Province." Journal Highway and Transportation Research and Development, 22 (5), 67-70.

[16] China Meteorological Data Sharing Service System. (2009). "Daily value data sets of China radiation international exchange station" and "Daily value data sets of climatic resources of Chinese ground international exchange station". http://cdc.cma.gov.cn. 